\title{
In-vitro Study: Camp Overshoot Caused by Chronic Morphine Alleviated by the Synergistic Combination of Zamzam Water and Methadone in Human Primary Glioblastoma Cell Line (U-87 MG)
}

\author{
Shariff Halim ${ }^{a}$, Nasir Mohamad ${ }^{b, c}$, Ridzuan PM$^{a}$, Nur Husna Zakariac ${ }^{c}$ Nur Atikah Muhammad \\ a International Medical School, Management \& Science University (MSU), 40100 Shah Alam, Selangor Darul \\ Ehsan, Malaysia. \\ ${ }^{\mathrm{b}}$ Faculty of Medicine, Universiti Sultan Zainal Abidin (UniSZA), 20400, Kuala Terengganu, Terengganu, \\ Malaysia. \\ 'Centre for Research in Addiction (CentRenA), Universiti Sultan Zainal Abidin (UniSZA), 21300, Gong Badak, \\ Terengganu, Malaysia.
}

\section{ABSTRACT}

Introduction: Zamzam water is blessed water originated from Mecca and is believed by Muslims to have the ability to cure illness. This ability to cure illness is due to the fact that zamzam water has higher concentration of minerals especially sodium, calcium and magnesium which play a vital role. Sodium is reported to be involved in the regulation of the Mu-Opioid Receptor, which indirectly leads to the production of cAMP. Hence, this current study was carried out to investigate the synergistic effects of zamzam water and methadone combination on CAMP levels in human primary glioblastoma cell line (U-87 MG) after chronic morphine administration. Materials and Methods: The time course and concentration of morphine on U-87 MG cell line was determined. The U-87 MG cell line was incubated with morphine $(25 \mu \mathrm{L} / \mathrm{mL})$ for $24 \mathrm{~h}$, to make the cell dependent on morphine and later treated with different combinations of $3.2 \mathrm{~mL}$ of zamzam water and methadone $(5,10,25 \mu \mathrm{L} / \mathrm{mL})$. The levels of CAMP was determined using the enzyme-linked immunosorbent assay kit. Results: The result revealed that $3.2 \mathrm{~mL}$ of zamzam water incubated with $10 \mu \mathrm{l} /$ $\mathrm{mL}$ of methadone significantly prevented the overshoot production of cAMP level $(p<0.05)$ in $U-87$ MG cell line after $48 \mathrm{~h}$ incubation when compared to the untreated samples. Conclusion: These finding suggest that co-treatment with zamzam water and methadone could possibly avoid tolerance and dependence on chronic morphine treatment by preventing the up-regulation of cAMP level.

KEYWORDS: Morphine, CAMP, Zamzam Water, Methadone

INTRODUCTION

Opioids such as morphine have been used for thousands of years for the treatment of pain. It is considered as the most powerful drug to relieve pain. However, the development of tolerance, dependence and severe withdrawal symptoms limit the long-term use after repeated opioid

Corresponding Author:

Dr. Halim Shariff

Senior Lecturer,

International Medical School,

Management and Science University (MSU)

Shah Alam, Selangor.

Tel No: +6014-2444007

Email: drhalim_shariff@msu.edu.my administration. These phenomenon is caused by the adaptation that occurred to counteract prolonged opioid receptor activation. ${ }^{1}$ Adaptive changes have been observed within the central nervous system at difference organization level. It involves from the alteration in receptor and cellular level to functional modifications of different neuronal networks. ${ }^{2-4}$ Cyclic adenosine 3',5'-cyclic monophosphate (cAMP) which is the second messenger produced by activation of adenylyl cyclases plays a very important role as a signal transducer in several pathologic and physiologic settings. Series of study have shown the involvement of CAMP in pain and opioid-induced analgesia. It has been reported that increased CAMP level is correlated with increase nociception. ${ }^{5}$ In the case of acute effects of opioid administration, activation of Mu-Opioid Receptor 
(MOR) by agonist will decrease the activity of adenylyl cyclase and thus reduce the level of CAMP. ${ }^{6}$ CAMP levels is among the most altered during the chronic administration of morphine. Chronic administration causes CAMP overshoot following the initial decrease in adenylyl cyclase activity. ${ }^{7}$ Similarly, Collier and Francis hypothesized that elevated CAMP level following chronic morphine exposure is related to opioid dependence. ${ }^{8}$

The best established molecular adaptation to chronic drug exposure is the up-regulation of cAMP pathway, a phenomenon first discovered in cultured neuroblastoma $X$ glioma cells ${ }^{9}$ and later demonstrated in neurons ${ }^{10}$ in response to repeated opiate administration. Acute opiate exposure inhibits the CAMP pathway in any types of neurons in the brain $^{11}$ whereas chronic opiate exposure leads to a compensatory up-regulation of the cAMP pathway in at least a subset of these neurons.

Zamzam water is natural water that comes from a well within the Holy Mosque about 20 meters east of Ka'ba in Mecca City. This city is regarded as the most sacred city for Muslims and is located in the western part of Saudi Arabia about $70 \mathrm{~km}$ south of the city of Jeddah on the coast of the Red Sea. Geographically, it is located at $1399 \mathrm{ft}$ above sea level at latitude $21^{0}$ 26' 48' $\mathrm{N}$, longitude $39^{\circ} 53^{\prime} 46^{\prime \prime} \mathrm{E} .^{12}$ Millions of Muslim drink zamzam water during pilgrimage and umrah each year and tend to bring back the water to their home country as a souvenir to their relatives. Studies on zamzam water have reported its therapeutic effects as an antioxidant, anticancer and radioprotective agent. ${ }^{13-15}$ In our previous study, we reported that the combination of zamzam water and methadone can reduce the morphine withdrawal symptoms in rats ${ }^{16,17}$ however we did not study on the cellular mechanism. Hence, the present study was designed to investigate the preventive effects of zamzam water and methadone combination treatment on CAMP level on human primary glioblastoma cell line (U-87 MG).

\section{MATERIAL AND METHODS}

\section{Materials}

Zamzam water was obtained directly from Mecca and was filtered using filter membrane $0.45 \mathrm{um}$ to prevent contamination. Human primary glioblastoma cell line (U-87 MG) which is an opioid receptor expressing cell, were a gift from Cell Culture Laboratory of UniSZA. RPMI 1640 medium, foetal bovine serum (FBS) and penicillin/streptomycin were purchased from Gibco (Invitrogen, USA). Morphine sulphate and methadone hydrochloride were obtained from PharmaServ Alliances. CAMP assay kit was obtained from ABNOVA (USA).

\section{Methods}

\section{$U-87 M G$}

U-87 MG were seeded at $2 \times 10^{5}$ cells/flask and grown in DMEM containing $10 \% \mathrm{FBS}$ and $1 \%$ penicillin/ streptomycin sulphate in a humidified $5 \% \mathrm{CO}_{2}$ at $37^{\circ}$ C until it reached $60-70 \%$ confluence.

\section{Optimization of Morphine Dependence on U-87 MG Cell Line}

U-87 MG cells $\left(2 \times 10^{5}\right.$ cells/well) were exposed to fresh cell culture medium containing different concentration of morphine $(5,10$, and $25 \mu \mathrm{L} / \mathrm{mL})$ to make the cells morphine dependent. Then, the cells were incubated in $5 \% \mathrm{CO}_{2}$ at $37^{\circ} \mathrm{C}$ for $0,6,24,48$ and 72 hours and were assayed using ELISA kit.

\section{Optimization of Effective Concentration and Time Course of Methadone}

After obtaining the time course and concentration for morphine dependence, the cells were then treated with fresh cell culture medium containing different concentration of methadone $(5,10$, and 25 $\mu \mathrm{L} / \mathrm{mL}$ ) to optimise the effective doses of methadone. Then, cells were incubated in $5 \% \mathrm{CO}_{2}$ at $37^{\circ} \mathrm{C}$ for $3,6,12$ and 24 hours and were assayed using ELISA kit.

\section{Treatment}

After obtaining the optimum concentration and time course of methadone for treatment, morphine dependent cells were treated with different compounds; zamzam water only, methadone only and co-treatment with zamzam water with methadone. For methadone only group, 10, 20 and $30 \mu \mathrm{g} / \mathrm{mL}$ of methadone was added into the fresh medium while for zamzam water only group, the growth medium was replaced with fresh medium containing $40 \%$ volume of zamzam water based on 
our previous study. ${ }^{18}$

For co-treatment group (zamzam water with methadone), the growth medium was replaced with fresh medium containing $40 \%$ volume of zamzam water and $10 \mu \mathrm{g} / \mathrm{mL}$ of methadone (obtained from the optimization). All the treatment groups then were incubated in $5 \% \mathrm{CO}_{2}$ at $37^{\circ} \mathrm{C}$ for 3,24 and 48 hours and were assayed using ELISA kit.

\section{Measurement of CAMP level}

Briefly, the medium of all treated and non-treated U-87 MG cell line in 96 well plated were aspirated and the cells washed with PBS. Then, the cells were washed directly with sample diluent for 10 minutes at room temperature and the cells were scraped off from the plate. Samples were centrifuged at $\geq 600 x$ $\mathrm{g}$ at $4^{\circ} \mathrm{C}$ for 15 minutes. The supernatants were collected and assayed directly by incubating the samples in the antibody-coated well. Reagents were added according to the protocol from the manufactures. The plate was sealed and shaken at room temperature for 2 hours. After washing several times, TMB substrate was added into each well and incubated for 30 minute followed by adding the stop solution. The results were determined by using a microplate reader set at $450 \mathrm{~nm}$.

\section{STATISTICAL ANALYSIS}

Data are presented as the mean \pm standard error (SE). Statistical data were analysed using either a one-way ANOVA, paired or unpaired Student's ttest, when appropriate. Statistical significance was considered at $p<0.05$.

\section{RESULTS AND CONCLUSION}

Figure 1 shows the level of CAMP in different concentrations and incubation periods of morphine in order to optimise the concentration and time course of the U-87 MG cell becoming morphine dependent. Morphine with different concentrations (5, 10 and $25 \mu \mathrm{M})$ were added to the different incubation medium at time $0,6,24,68$ and $72 \mathrm{~h}$. The result showed that at $5 \mu \mathrm{M}$ of morphine, there was insignificant difference in the cAMP level as compared to the control. In contrast, cells exposed to morphine for $48 \mathrm{~h}$ produced chronic morphine dependence as shown by the increase in the CAMP level when compared to the control cell $(p<0.05)$.
These effects were observed when the cells were exposed to morphine at higher concentrations, i.e. 10 and $25 \mu \mathrm{M}$. At the cellular level, morphine dependence is characterised by a significant elevation of CAMP levels.

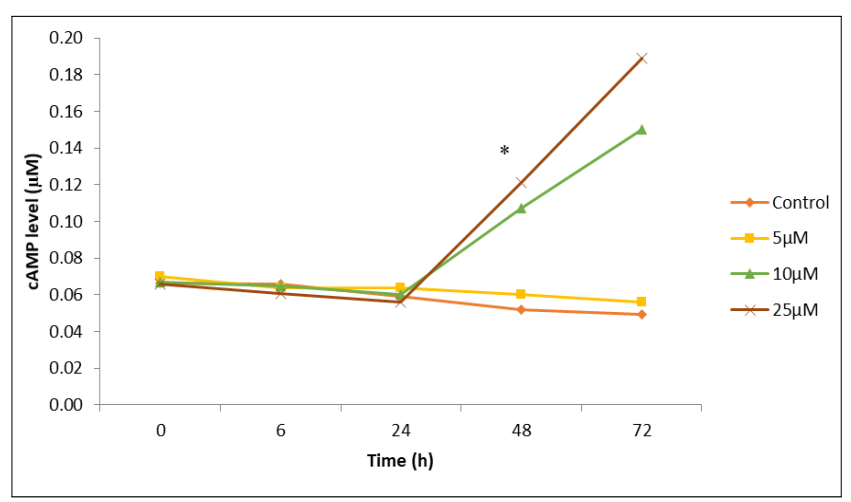

Figure 1: Levels of CAMP at different concentrations and incubation periods of morphine. Cells will become morphine dependent after incubation with 10 and $25 \mu \mathrm{M}$ of morphine at $48 \mathrm{~h}$ onwards.

*statistically significant compared to control group $(p<0.05)$.

To determine the effective concentration and time course of methadone, the U-87 MG cell line was exposed to $10 \mu \mathrm{M}$ of morphine for $48 \mathrm{~h}$ and followed by a series of treatment with methadone of different concentrations $(5,10$ and $15 \mu \mathrm{M})$. Methadone is the common drug prescribed in the treatment of opioid addiction because it has been proven to prevent the compensatory increase in intracellular cAMP after chronic morphine administration. ${ }^{19}$ As expected there was a clear reduction of CAMP level in methadone-treated cell line $(p<0.05)$.

Methadone was shown to inhibit the cAMP levels induced by morphine at concentrations of 10 and 15 $\mu \mathrm{M}$ after $6 \mathrm{~h}$ of incubation as shown in Figure 2 . Further study was carried out to determine whether the combination treatment of zamzam water and methadone will block the up-regulation of CAMP produced by morphine dependent U-87 MG cell line. In this combination, $10 \mu \mathrm{M}$ of methadone and $3.2 \mathrm{~mL}$ of zamzam water were incubated at difference incubation periods of $3,6,12$ and 24 hours. The levels of CAMP was significantly reduced $(p<0.05)$ in the samples which received the combination of zamzam water and methadone as compared to the methadone only group as shown in Figure 3. These effects were observed when the cells were treated with zamzam water and methadone for 12 and 24 hour. 


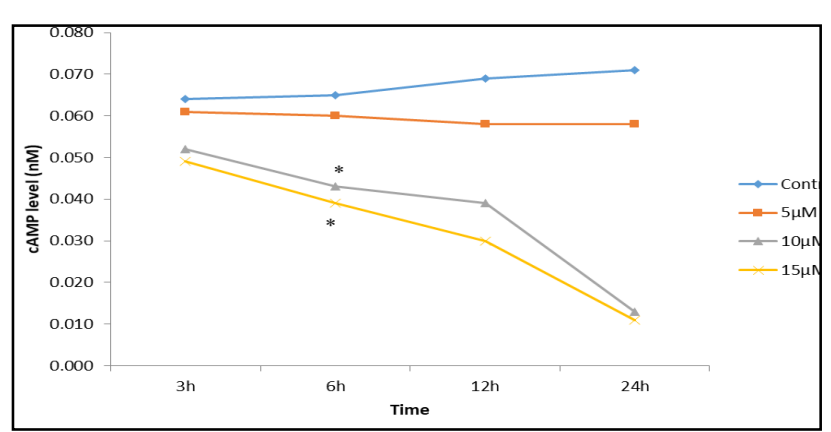

Figure 2: Levels of CAMP in different concentrations and incubation periods of methadone. After cells were incubated with $10 \mu \mathrm{M}$ of morphine for $48 \mathrm{~h}$, cells were then treated to different concentrations of methadone $(5$, 10 and $15 \mu \mathrm{M})$. Methadone was shown to significantly inhibit the CAMP level induced by morphine at 10 and 15 $\mu \mathrm{M}$ after $6 \mathrm{~h}$ incubation.

* statistically significant compared to control group $(p<0.05)$.

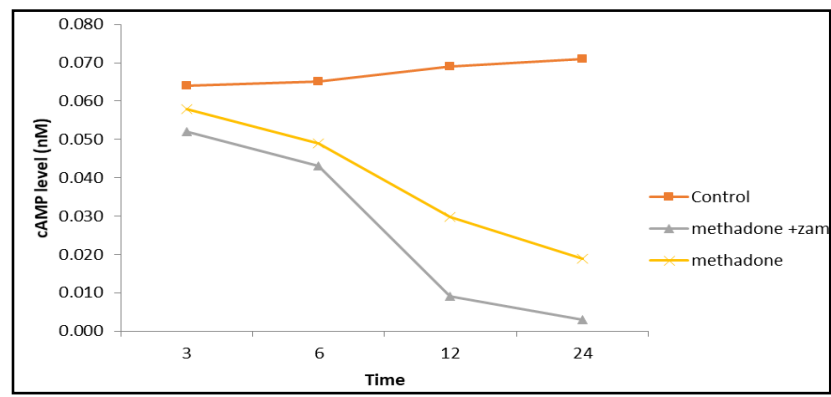

Figure 3: Levels of CAMP in different treatment incubation periods. After cells were incubated with $10 \mu \mathrm{M}$ of morphine for $48 \mathrm{~h}$, cells were then treated with $10 \mu \mathrm{M}$ of methadone only and combination of $10 \mu \mathrm{M}$ of methadone with $3.2 \mathrm{~mL}$ of zamzam water. Combination of zamzam water and methadone was shown to significantly inhibit the CAMP levels induced by morphine after $12 \mathrm{~h}$ incubation.

*statistically significant compared to morphine only group $(p<0.05)$

There is large volume of published studies proving chronic exposure of opioids can cause adaptations in some intracellular messenger pathways in several brain regions. It is well understood that the bestestablished mechanism underlying the development of opioid dependence and withdrawal is the upregulation of CAMP pathway. ${ }^{20}$ This up-regulation and the subsequent activation of the transcription factor CREB have been identified as major contributing factor for tolerance and dependence..$^{21,22}$

In this current study, the changes in CAMP at cellular level after treatment with methadone only and combination of zamzam water and methadone were examined using ELISA kit. Human primary glioblastoma formally known as cell line U-87 MG cell line were used and analysed for the level of CAMP. The reason of choosing U-87 MG cell line is due to the ability of this cell to express MOR, in which it is a receptor that is involved with opioid dependence and tolerance. ${ }^{23}$

The effects of morphine on CAMP production using different concentrations of morphine were examined. It this study, morphine sulphate at the concentration levels of 5,10 and $25 \mu \mathrm{M}$ reduces CAMP production at $6 \mathrm{~h}$ until $24 \mathrm{~h}$. Whereas morphine sulphate at the concentration levels of 10 and $25 \mu \mathrm{M}$ increase in cAMP level from $48 \mathrm{~h}$ until 72 $h$ as shown in Figure 1 . This suggests that the development of chronic morphine dependence starts from $48 \mathrm{~h}$ onward manifested by a rebound of CAMP production. This finding is in line with previous research findings ${ }^{24,25}$ which proved that chronic morphine exposure effectively increases cAMP levels.

Subsequently, the effects of cAMP production after treatment with methadone only, zamzam water only and co-treatment with zamzam water and methadone were measured. The results of the present studies showed that treatment with methadone only reduced the level of CAMP when compared to non-treated cell after $6 \mathrm{~h}$. Methadone only was used as a positive control in this study. These results suggest that methadone can prevent chronic morphine treatment-induced adaptive sensitization or overshoot of adenylate cyclase activity. ${ }^{19}$ Methadone and morphine are similar opioid receptor agonists but methadone has a lower dependence potential than morphine and is effectively used in the treatment of opioid addiction, whereas morphine induces dependence. ${ }^{26}$

A similar effect was observed when cells were incubated with morphine only for $48 \mathrm{~h}$ then treated with either $3.2 \mathrm{~mL}$ zamzam water only for $12 \mathrm{~h}$ or combination of $3.2 \mathrm{~mL}$ of zamzam water and methadone $(10 \mu \mathrm{M})$. These results suggested zamzam water only and combination of zamzam water and methadone can prevent the overshoot of CAMP. The reason for this is not clear but it may be related to the high mineral content especially sodium in zamzam water which gives a synergistic 
effect when combine with methadone. Previous study has shown that sodium can facilitate $G$ protein activation which leads to the endocytosis process of MOR. Endocytosis was reported to have the tendency to alleviate opioid dependence. ${ }^{27}$ This will prevent the overshoot level of CAMP in U-87 MG cell line.

\section{ACKNOWLEDGEMENT}

The publication of this article is supported by NRGS RR057-1 and the author would like to thank to International Medical School, MSU and CentRenA for their support.

\section{CONFLICT OF INTEREST}

The authors declare no conflict of interest.

\section{REFERENCES}

1. He $\mathrm{YL}$, Zhang $\mathrm{CL}$, Gao XF, et al. Cyproheptadine Enhances the IK of Mouse Cortical Neurons through Sigma-1 ReceptorMediated Intracellular Signal Pathway. PLoS One 2012; 7(7): e41303

2. Allouche $S$, Noble F, Marie N. Opioid receptor desensitization: mechanisms and its link to tolerance. Frontiers in pharmacology 2014; 5:280

3. Christie MJ. Cellular neuroadaptations to chronic opioids: tolerance, withdrawal and addiction. British journal of pharmacology 2008; 154(2):384-396.

4. Al-Hasani R, Bruchas MR. Molecular mechanisms of opioid receptor-dependent signalling and behavior. Anesthesiology: The Journal of the American Society of Anesthesiologists. 2011; 115(6):1363-1381.

5. Hucho T, Levine JD. Signalling pathways in sensitization: toward a nociceptor cell biology. Neuron. 2007; 55(3):365-376

6. Gupta S, Kulhara P. Cellular and molecular mechanisms of drug dependence: An overview and update. Indian journal of psychiatry. 2007; 49(2):85.

7. Sharma SK, Klee WA, Nirenberg M. Dual regulation of adenylate cyclase accounts for narcotic dependence and tolerance. ProcNatlAcadSciUSA. 1975; 72(8):3092-3096.

8. Collier HO, Francis DL. Morphine abstinence is associated with increased brain cyclic AMP. Nature. 1975; 255(5504):159-162.
9. Sharma SK, Nirenberg M, Klee WA. Morphine receptors as regulators of adenylate cyclase activity. Proceedings of the National Academy of Sciences. 1975; 72(2):590-594.

10. Nestler EJ. Molecular mechanisms of drug addiction. J Neurosci. 1992; 12(7):2439-2450.

11. Childers SR. Opioid receptor-coupled second messenger systems. Life sciences. 1999; 48 (21).

12. Khalid N, Ahmad A, Khalid S, Ahmed A, Irfan M. Mineral composition and health functionality of zamzam water: a review. International journal of food properties. 2014; 17(3):661-77.

13. Abdelsalam E, Abdullah B, Khaled A. Antioxidant effects of Zamzam water in normal rats and those under induced-oxidative stress. Journal of Medicinal Plants Research. 2012; 6(42):5507-5512.

14. Al Doghaither HA, Al-Ghafari AB, Rahimulddin $\mathrm{SA}$, et al. Evaluation of the Potential Anticancer Activity of Zamzam Water in Human Colon Cancer Cell Line. Cancer and Oncology Research. 2016; 4(3):33-41.

15. Yazdi FK, Monfared AS, Tashakkorian H, Mahmoudzadeh A, Borzoueisileh S. Radioprotective effect of Zamzam (alkaline) water: A cytogenetic study. Journal of environmental radioactivity. 2017; 167:166169.

16. Halim S, Mohamad N, Toriman ME, et al. Effects of Zamzam Water Alone or in Combination with Methadone on Attenuation of Spontaneous Withdrawal Symptoms in Morphine-Dependent Rats: A Behavioural Study. Advanced Science Letters. 2017; 23 (5):4492-4495.

17. Halim S, Mohamad N, Bakar NHA, et al. Effect of Zamzam Water Alone or in Combination with Methadone on Animal Withdrawal Symptoms in Morphine Dependent Rats. Research Journal of Pharmacy and Technology. 2017; 10(11): 3783-3788.

18. Halim S, Mohamad N, Toriman ME, Bakar NH, Latif AZ. Zamzam Water: Influence of Containers on Ionic Concentration and In-vitro Cytotoxic Effects on U87 Cell Line. Malaysian Journal of Applied Sciences. 2016;1(1):68-72.

19. Liu JG, Liao XP, Gong ZH, Qin BY. The difference between methadone and morphine in regulation of $\delta$-opioid receptors underlies 
the antagonistic effect of methadone on morphine-mediated cellular actions. European journal of pharmacology. 1999;373(2-3):233239.

20. Nestler EJ, Aghajanian GK. Molecular and cellular basis of addiction. Science. 1997;278 (5335):58-63.

21. Duman RS, Tallman JF, Nestler EJ. Acute and chronic opiate-regulation of adenylate cyclase in brain: specific effects in locus coeruleus. Journal of Pharmacology and Experimental Therapeutics. 1988; 246(3):1033-1039.

22. Nestler EJ, Tallman JF. Chronic morphine treatment increases cyclic AMP-dependent protein kinase activity in the rat locus coeruleus. Molecular Pharmacology. 1988; 33 (2):127-132.

23. Byrne LS, Peng J, Sarkar S, Chang SL. Interleukin-1 beta-induced up-regulation of opioid receptors in the untreated and morphine-desensitized U87 MG human astrocytoma cells. Journal of neuroinflammation. 2012; 9(1):252.

24. Coven E, Ni Y, Widnell KL, et al. Cell TypeSpecific Regulation of CREB Gene Expression: Mutational Analysis of CREB Promoter Activity. Journal of neurochemistry. 1998; 71(5):18651874.

25. Widnell KL, Russell DS, Nestler EJ. Regulation of expression of CAMP response elementbinding protein in the locus coeruleus in vivo and in a locus coeruleus-like cell line in vitro. Proceedings of the National Academy of Sciences. 1994; 91(23):10947-10951.

26. Berger AC, Whistler JL. How to design an opioid drug that causes reduced tolerance and dependence. Annals of neurology. 2010; 67 (5):559-569.

27. Koch T, Widera A, Bartzsch K, et al. Receptor endocytosis counteracts the development of opioid tolerance. Molecular pharmacology. 2004; 67(1):280-287. 